\title{
Mineral-Oxide-Doped Aluminum Titanate Ceramics with Improved Thermomechanical Properties
}

\author{
R. Papitha, ${ }^{1}$ M. Buchi Suresh,, ${ }^{1}$ Dibakar Das, ${ }^{2}$ and Roy Johnson ${ }^{1}$ \\ ${ }^{1}$ Center for Ceramic Processing, International Advanced Research Centre for Powder Metallurgy and New Materials (ARCI), \\ Balapur, Hyderabad 500005, India \\ ${ }^{2}$ School of Engineering Sciences and Technology, University of Hyderabad, Hyderabad 500046, India \\ Correspondence should be addressed to Roy Johnson; royjohnson@arci.res.in
}

Received 31 May 2012; Accepted 10 July 2012

Academic Editor: Zhenxing Yue

Copyright (C) 2013 R. Papitha et al. This is an open access article distributed under the Creative Commons Attribution License, which permits unrestricted use, distribution, and reproduction in any medium, provided the original work is properly cited.

Investigations were carried out, on the effect of addition of kaolinite $\left(2 \mathrm{Al}_{2} \mathrm{O}_{3} \cdot 3 \mathrm{SiO}_{2} \cdot 2 \mathrm{H}_{2} \mathrm{O}\right)$ and talc $\left(\mathrm{Mg}_{3} \mathrm{Si}_{4} \mathrm{O}_{10}(\mathrm{OH})_{2}\right)$ in terms of bulk density, XRD phases, microstructure, as well as thermal and mechanical properties of the aluminium titanate (AT) ceramics. AT ceramics with additives have shown enhanced sinterability at $1550^{\circ} \mathrm{C}$, achieving close to $99 \%$ of TD (theoretical density) in comparison to $87 \% \mathrm{TD}$, exhibited with pure AT samples sintered at $1600^{\circ} \mathrm{C}$, and found to be in agreement with the microstructural observations. XRD phase analysis of samples with maximum densities resulted in pure AT phase with a shift in unit cell parameters suggesting the formation of solid solutions. TG-DSC study indicated a clear shift in AT formation temperature with talc addition. Sintered specimens exhibited significant reduction in linear thermal expansion values by $63 \%\left(0.42 \times 10^{-6} / \mathrm{C},\left(30-1000^{\circ} \mathrm{C}\right)\right)$ with talc addition. Thermal hysteresis of talc-doped AT specimens showed a substantial increase in hysteresis area corresponding to enhanced microcrack densities which in turn was responsible to maintain the low expansion values. Microstructural evaluation revealed a sizable decrease in crack lengths and 200\% increase in flexural strength with talc addition. Results are encouraging providing a stable formulation with substantially enhanced thermomechanical properties.

\section{Introduction}

Aluminum Titanate $\left(\mathrm{Al}_{2} \mathrm{TiO}_{5}\right.$, designated as $\left.\mathrm{AT}\right)$ ceramics exhibit excellent thermal properties such as low thermal expansion coefficient in the range of $1.0-1.5 \times 10^{-6} / \mathrm{C}$ (RT$\left.1000^{\circ} \mathrm{C}\right)$ in combination with low thermal conductivity $\left(\sim 1.5 \mathrm{Wm}^{-1} \mathrm{~K}^{-1}\right)$ and a high melting temperature of $1860^{\circ} \mathrm{C}$ [1-4]. This makes $\mathrm{Al}_{2} \mathrm{TiO}_{5}$, a material of choice for many refractory applications. Some of these applications include wall flow filters for diesel particulate emission control, exhaust port liners in automotive engines and thermal shock resistant refractory parts for nonferrous metallurgical industries [5-8]. One of the disadvantages of this ceramic material for practical applications is the low flexural strength due to the extensive microcracks generated whil processing $[3,4$, 9]. Crystal structure of aluminum titanate $\left(\beta-\mathrm{Al}_{2} \mathrm{TiO}_{5}\right)$ is pseudo-brookite and is associated with the strong anisotropy in crystallographic axis while heating, which is responsible for microcracking on cooling $[9,10]$. The microcracking phenomenon is closely related to the material microstructure. Below a critical grain size, the elastic energy of the system is insufficient for microcrack formation during cooling and thus the mechanical properties are considerably enhanced. Additionally, eutectoid decomposition to its parent oxides such as $\alpha-\mathrm{Al}_{2} \mathrm{O}_{3}$ and $\mathrm{TiO}_{2}$ between 750 to $1280^{\circ} \mathrm{C}$ is also an issue leading to thermal instability of the $\mathrm{Al}_{2} \mathrm{TiO}_{5}$ phase. This decomposition occurs when the adjacent $\mathrm{Al}^{3+}(0.54 \AA)$ and $\mathrm{Ti}^{4+}(0.67 \AA)$ octahedra collapse, because of the lattice site occupied by the $\mathrm{Al}^{3+}$ ion is too large. The thermal energy available from this collapse allows $\mathrm{Al}^{3+}$ to migrate from its position and causes structural dissolution to rutile $\left(\mathrm{TiO}_{2}\right)$ and corundum $\left(\alpha-\mathrm{Al}_{2} \mathrm{O}_{3}\right)[9-12]$.

It is also well known that, thermomechanical properties of microcracked ceramics is a function of dopants and many attempts to dope with various oxide compounds (such as $\mathrm{MgO}, \mathrm{ZrO}_{2}, \mathrm{Fe}_{2} \mathrm{O}_{3}, \mathrm{SiO}_{2}, \mathrm{ZrSiO}_{4}$ ) are made so far [13-19]. These oxides are reported to be effective in densification and improving the thermal stability. However, they need 
to be doped in high-volume fractions, deteriorating the thermal properties and long-term stability [15]. Doping with spodumene $\left(\mathrm{LiAlSiO}_{4}\right)$, mullite $\left(3 \mathrm{Al}_{2} \mathrm{O}_{3} \cdot 2 \mathrm{SiO}_{2}\right)$, cordierite $\left(\mathrm{Mg}_{2} \mathrm{Al}_{4} \mathrm{Si}_{5} \mathrm{O}_{18}\right)$, and feldspar have also been attempted, but and no significant enhancement in thermomechanical properties were reported [19-25]. Studies have also attempted to dope with $\mathrm{SiO}_{2}$ (9 wt\%) and co-doping with $\mathrm{MgO}$ (10 wt\%) and $\mathrm{SiO}_{2}(8 \mathrm{wt} \%)$, which have reported significant enhancement in stability and mechanical properties. However, doping with $\mathrm{SiO}_{2}$ resulted in unreacted residual $\mathrm{TiO}_{2}$ phase and the formation of additional phases such as $\mathrm{MgAl}_{2} \mathrm{O}_{4}$ and $\mathrm{Mg}_{2} \mathrm{SiO}_{4}$ with co-doping [17].

In view of the above, the objective of this paper is to elucidate systematically the effect of additives such as kaolinite and talc into $\mathrm{Al}_{2} \mathrm{TiO}_{5}$ formulation with varying concentrations followed by the evaluation of thermomechanical properties. Accordingly, precursor oxide samples were compacted with and without additives and were subjected to sintering at varying temperatures to achieve close to theoretical density. Sintering behavior of AT was elucidated with dilatometric shrinkage curve and DSC studies. Sintered samples were characterized for their density, phase, microstructure, and CTE measurements. Further, the thermal hysteresis was recorded while heating and cooling using dilatometer. Flexural (3-point bend) strength was also determined and correlated with microcrack densities, observed with fractograph.

\section{Experimental Procedure}

Basic raw materials such as alumina $\left(\mathrm{Al}_{2} \mathrm{O}_{3}\right.$, Baikowski, France) and titania $\left(\mathrm{TiO}_{2}\right.$, Qualigens) powders along with the additives kaolinite $\left(2 \mathrm{Al}_{2} \mathrm{O}_{3} \cdot 3 \mathrm{SiO}_{2} \cdot 2 \mathrm{H}_{2} \mathrm{O}\right)$ and talc $\left(\mathrm{Mg}_{3} \mathrm{Si}_{4} \mathrm{O}_{10}(\mathrm{OH})_{2}\right)$ were used for the investigations. XRD phase analysis of the raw materials was carried out by Bruker's D8 advanced system and morphology and particle size analysis by scanning electron microscope (S-4300SE/N, Hitachi, Tokyo, Japan). Physiochemical properties of the raw materials are depicted in Table 1 . The concentration of silica $(1.5,3$, and $4.5 \mathrm{wt} \%)$ in aluminum titanate and sample ID's $\left(\mathrm{C}_{0}, \mathrm{C}_{1}, \mathrm{C}_{2}, \mathrm{C}_{3}, \mathrm{C}_{4}, \mathrm{C}_{5}\right.$, and $\left.\mathrm{C}_{6}\right)$ were depicted in Table 2. The formulations were granulated with $2 \mathrm{wt} \%$ of poly vinyl alcohol as a binder and compacted into green compacts of $65 \mathrm{~mm} \times 65 \mathrm{~mm} \times 8 \mathrm{~mm}$ using a hydraulic press. The green density of the compacted samples was measured by the dimensional method and was found to be greater than $50 \%$ of the theoretical density (estimated by the rule of mixtures). In order to study, the extent of physiochemical changes occurring in green specimens over the processing temperature ranges, the specimens were subjected to the differential scanning calorimetric (DSC) analysis using TG-DSC analyzer (Netzsch, Germany) from room temperature to $1550^{\circ} \mathrm{C}$. Basic formulation of $\mathrm{Al}_{2} \mathrm{TiO}_{5}$ $\left(\mathrm{C}_{0}\right)$ has been subjected to dilatometry (Netzsch 402C, Germany) and the shrinkage profile was recorded with respect to the temperature. Three sintering temperatures of $1500^{\circ} \mathrm{C}, 1525^{\circ} \mathrm{C}$, and $1550^{\circ} \mathrm{C}$ were selected for the sintering of all formulations and selection of optimum sintering temperature.
Densities of the samples sintered at different temperatures were evaluated by widely used Archimedes principle (ASTM 792) and phases were analysed by XRD (Bruker's D8 advanced XRD). The polished samples were thermally etched at a temperature, $50^{\circ} \mathrm{C}$ below the sintering temperature for microstructural observations using a scanning electron microscope (S-4300SE/N, Hitachi, Tokyo, Japan). The specimens were also subjected to dilatometric analysis using a push-rod-type dilatometer (Netzsch 402C, Germany) incorporating the sample holder correction to determine coefficient of linear expansion (CTE). Thermal hysteresis was recorded for the samples of $\mathrm{C}_{0}, \mathrm{C}_{3}$, and $\mathrm{C}_{5}$ formulations with additives which have exhibited the highest densities. Sintered samples with the highest densities were also machined to the rectangular specimens of $45 \mathrm{~mm} \times 4 \mathrm{~mm} \times 3 \mathrm{~mm}$ for the determination of the flexural strength using 3 -point bend test following ASTM C-1161-02C (Instron).

\section{Results and Discussion}

3.1. Characterisation of Raw Materials. XRD patterns and SEM micrographs of the basic raw materials recorded for $\mathrm{Al}_{2} \mathrm{O}_{3}$ and $\mathrm{TiO}_{2}$ used for the present investigations are shown in Figures 1(a), 1(b), 1(c), and 1(d), respectively. XRD pattern of $\mathrm{Al}_{2} \mathrm{O}_{3}$ indicated the coexistence of $\alpha$-phase $(\sim 85 \%)$ as a major phase along with $\gamma$-phase $(\sim 15 \%)$ and $\mathrm{TiO}_{2}$ powder has shown single anatase phase. SEM micrographs of both the basic powders have shown an irregular morphology with an average particle size of 150 and $300 \mathrm{~nm}$, respectively.

\subsection{Characterisation of Sintered Specimens}

3.2.1. Densification of $\mathrm{Al}_{2} \mathrm{TiO}_{5}$ with and without Additives. Variation of bulk densities with sintering temperature for all the compositions is shown in Figures 2(a) and 2(b). It is evident that the bulk density of $\mathrm{Al}_{2} \mathrm{TiO}_{5}$ formulation without additives has shown only a marginal increase from 84 to $85 \%$ of TD with increase of sintering temperature from 1500 to $1550^{\circ} \mathrm{C}$. No significant increase in density is observed even at a sintering temperature of $1600^{\circ} \mathrm{C}$. Composition, concentration, and sintering temperature are to found have a significant effect on the final density values. Concentrations of both the additives are fixed based on their silica content (Table 1) in such a way that the final formulation corresponds to a silica addition of $1.5,3$, and $4.5 \%$ (Table 2). Kaolinite $\left(2 \mathrm{Al}_{2} \mathrm{O}_{3} \cdot 3 \mathrm{SiO}_{2} \cdot 2 \mathrm{H}_{2} \mathrm{O}\right)$ addition from 2.9 to $8.8 \%$ has resulted in the consistent increase in density from $90 \%$ to a maximum density of $99 \%$ of TD. Talc $\left(\mathrm{Mg}_{3} \mathrm{Si}_{4} \mathrm{O}_{10}(\mathrm{OH})_{2}\right)$ addition from 2.5 to $5 \%$ increases the density from 92 to $98.63 \%$; however, unlike kaolinite, a higher concentration of talc $\left(\mathrm{Mg}_{3} \mathrm{Si}_{4} \mathrm{O}_{10}(\mathrm{OH})_{2}\right)$ has not shown any significant increase in density beyond $92 \%$.

Dilatometric curve of $\mathrm{Al}_{2} \mathrm{TiO}_{5}$ depicted in Figure 3(a) clearly shows an initial shrinkage corresponding to the in-situ reaction sintering of the starting mixture of $\mathrm{Al}_{2} \mathrm{O}_{3}$ and $\mathrm{TiO}_{2}$ followed by an expansion regime corresponding to formation of $\mathrm{Al}_{2} \mathrm{TiO}_{5}$ and is in good agreement with endothermic peak at $1375^{\circ} \mathrm{C}$ (Figure 3(b)). This expansion regime in 


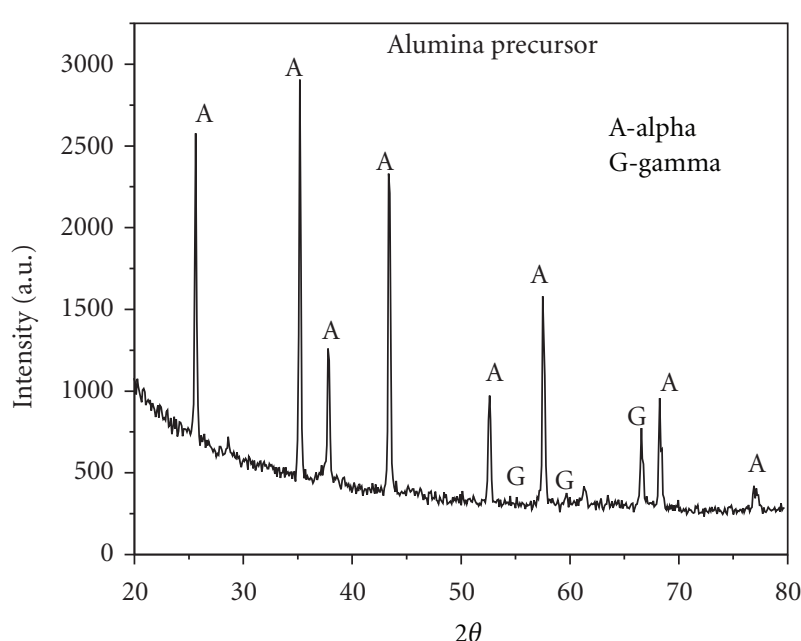

(a)

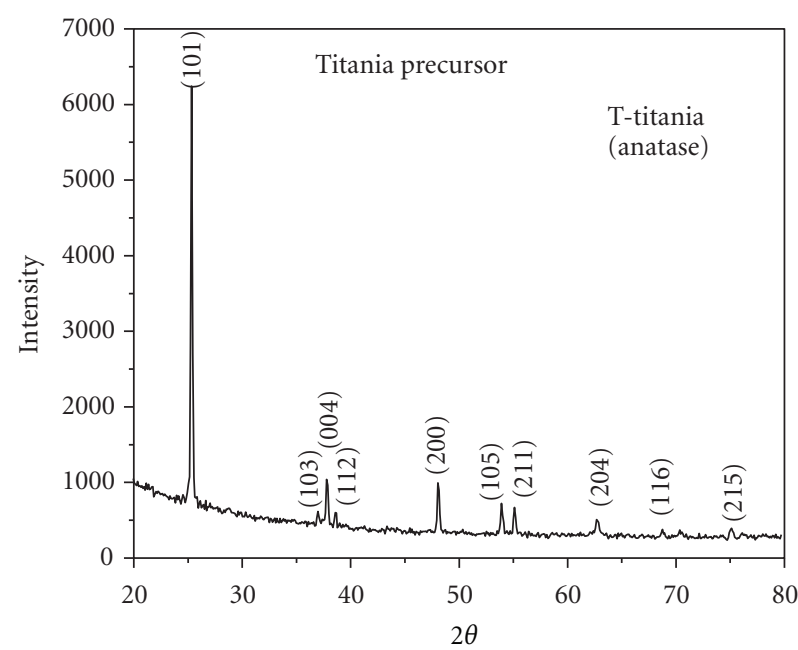

(c)

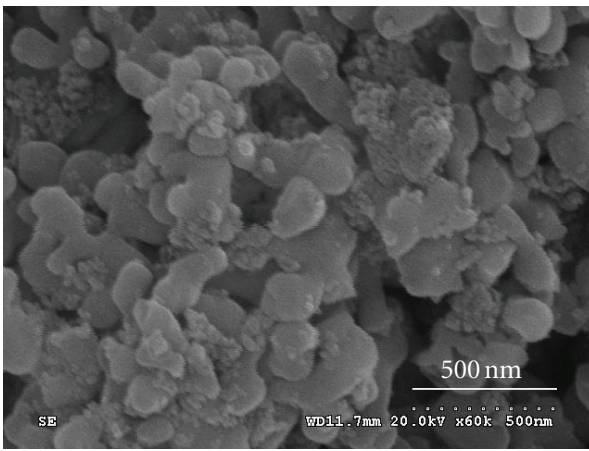

(b)

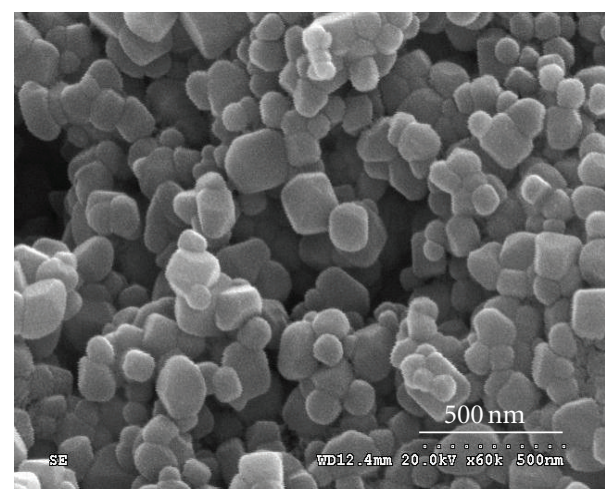

(d)

Figure 1: (a) XRD pattern of $\mathrm{Al}_{2} \mathrm{O}_{3}$ powder, (b) morphology of $\mathrm{Al}_{2} \mathrm{O}_{3}$ powder, (c) $\mathrm{XRD}$ pattern $\mathrm{TiO}_{2}$ powder, and (d) morphology of $\mathrm{TiO}_{2}$ powder.

TABLE 1: Physiochemical properties of raw materials.

\begin{tabular}{|c|c|c|c|c|}
\hline Property & Alumina & Titania & Talc & Kaolinite \\
\hline \multicolumn{5}{|l|}{ Chemical composition wt\% } \\
\hline $\mathrm{SiO}_{2}$ & & & 60.0 & 44.0 \\
\hline $\mathrm{Al}_{2} \mathrm{O}_{3}$ & 99.95 & & 2.1 & 50.2 \\
\hline $\mathrm{TiO}_{2}$ & & 99.5 & 0.08 & 0.4 \\
\hline $\mathrm{MgO}$ & 0.005 & & 31.1 & $<0.1$ \\
\hline $\mathrm{Na}_{2} \mathrm{O}$ & & & $<0.01$ & 0.11 \\
\hline $\mathrm{K}_{2} \mathrm{O}$ & & & $<0.01$ & $<0.01$ \\
\hline \multicolumn{5}{|l|}{ Physical properties } \\
\hline Average particle size $\left(D_{50}\right)$ & $200 \mathrm{~nm}$ & $300 \mathrm{~nm}$ & $21.62 \mu \mathrm{m}$ & $2.86 \mu \mathrm{m}$ \\
\hline Crystalline phase & $\alpha$ and $\gamma$ & Anatase & Talc & Kaolinite \\
\hline
\end{tabular}




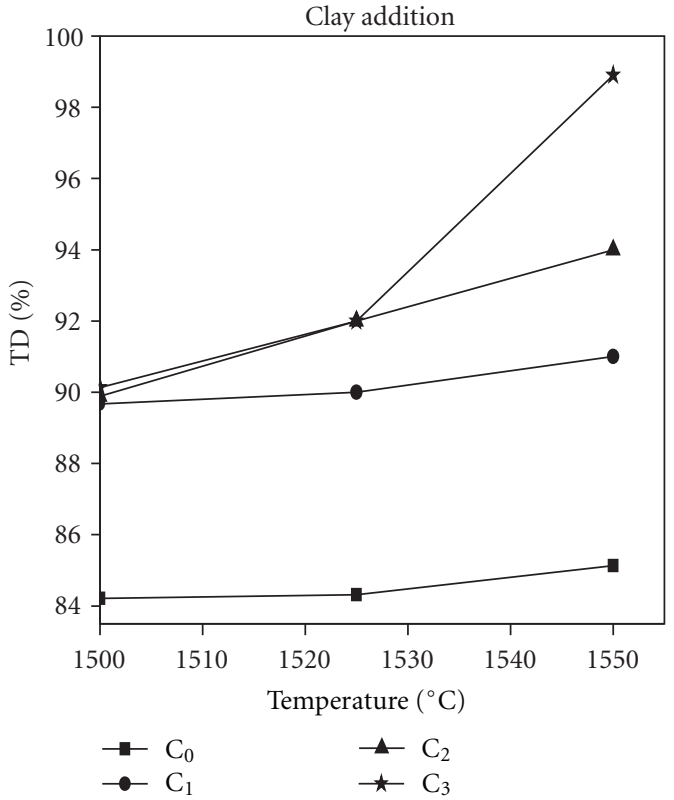

(a)

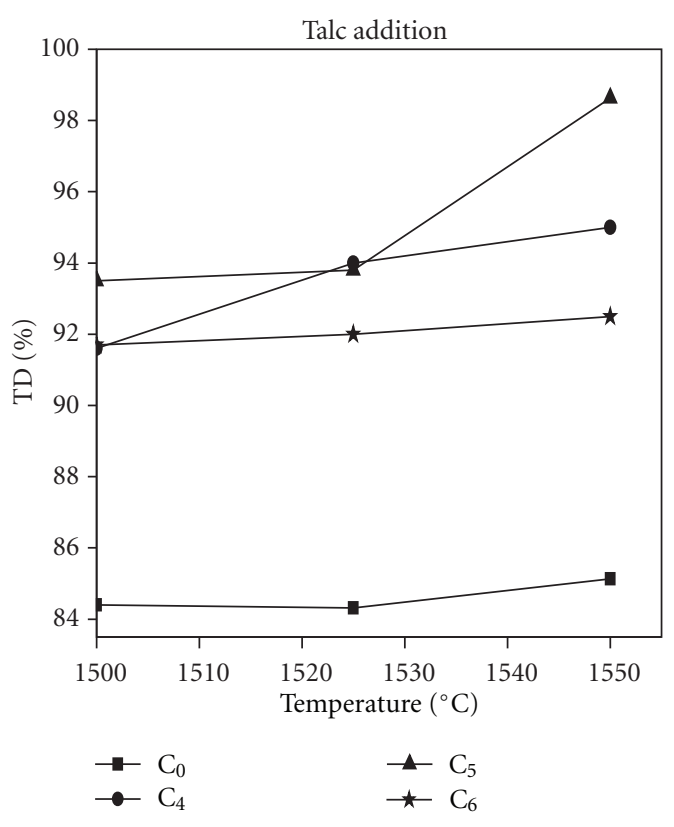

(b)

Figure 2: (a) Density variation with temperature of $\mathrm{C}_{0}, \mathrm{C}_{1}, \mathrm{C}_{2}, \mathrm{C}_{3}$, and (b) Density variation with temperature of $\mathrm{C}_{0}, \mathrm{C}_{4}, \mathrm{C}_{5}$, and $\mathrm{C}_{6}$.

TABLE 2: Formulation investigated (wt\%).

\begin{tabular}{|c|c|c|c|c|c|}
\hline Sr. No. & Sample. ID & $\mathrm{Al}_{2} \mathrm{O}_{3}$ & $\mathrm{TiO}_{2}$ & Clay & Talc \\
\hline 1 & $\mathrm{C}_{0}$ & 56 & 44 & 0 & 0 \\
\hline 2 & $\mathrm{C}_{1}$ & 55.16 & 43.34 & $2.94 \%$ & 0 \\
\hline 3 & $\mathrm{C}_{2}$ & 54.32 & 42.68 & $5.88 \%$ & 0 \\
\hline 4 & $\mathrm{C}_{3}$ & 53.48 & 42.02 & $8.82 \%$ & 0 \\
\hline 5 & $\mathrm{C}_{4}$ & 55.16 & 43.34 & 0 & $2.5 \%$ \\
\hline 6 & $\mathrm{C}_{5}$ & 54.32 & 42.68 & 0 & $5 \%$ \\
\hline 7 & $\mathrm{C}_{6}$ & 53.48 & 42.02 & 0 & $7.5 \%$ \\
\hline
\end{tabular}

fact offsets the densification of AT matrix by around $20 \%$, resulting in poor sintered density of $87 \%$ even at a sintering temperature of $1600^{\circ} \mathrm{C}$. Endothermic peak at $1386^{\circ} \mathrm{C}$ for $\mathrm{C}_{3}$, indicate that there is no significant shift in $\mathrm{Al}_{2} \mathrm{TiO}_{5}$ phase formation compared to undoped $\left(\mathrm{C}_{0}\right)$ formulation (Figure $3(\mathrm{~b})) . \mathrm{Al}_{2} \mathrm{TiO}_{5}$ phase formation temperature is shifted to a lower temperature range of $1274^{\circ} \mathrm{C}$ for $\mathrm{C}_{5}$ compared to $1375^{\circ} \mathrm{C}$ observed with $\left(\mathrm{C}_{0}\right)$ un-doped formulation as is evident from the DSC peak (Figure 3(b)).

XRD pattern of the maximum dense sample $\left(C_{3}\right)$ depicted in Figure 4 has not shown any additional peaks and all the peaks could be indexed with standard $\mathrm{Al}_{2} \mathrm{TiO}_{5}$ phase. However, a shift in unit cell constants is observed in comparison to the pure $\mathrm{Al}_{2} \mathrm{TiO}_{5}$ samples, especially in the case of " $c$ " parameter $[10,17]$. The cell parameters and volume of $\mathrm{C}_{0}$ sample are $a=9.4315 \AA, b=9.6385 \AA, c=3.590 \AA$, and $326.35(\AA)^{3}$, where as cell parameters and volume of sample $\mathrm{C}_{3}$ are $a=9.4342 \AA, b=9.6536 \AA, c=3.5940 \AA$, and
$327.32(\AA)^{3}$. The change in unit cell parameter is probably due to silicon $\left(\mathrm{Si}^{4+}\right.$, ionic radius $\left.=0.41 \AA\right)$ replacing $\mathrm{Al}^{3+}$ in the lattice of $\mathrm{Al}_{2} \mathrm{TiO}_{5}$ matrix. This may result in the multivalent state for titanium that is, $\mathrm{Ti}^{3+} / \mathrm{Ti}^{4+}$, corresponding to a stoichiometry of $\left(\left(\mathrm{Al}^{3+}, \mathrm{Ti}^{3+}\right)_{2}\left(\mathrm{Ti}^{4+}\right)_{1}\left(\mathrm{O}^{2-}\right)_{5}\right)$ which in turn enhances the sintering process. A closer look at the micrographs also reveals a change in the porous lamellar type of structure in to relatively dense faceted grains. Further, the microcracks are found visible and crack lengths are reduced to a greater extent in comparison to $\mathrm{C}_{0}$ with no additives.

XRD pattern of $\mathrm{C}_{5}$ sample with maximum density depicted in Figure 4 has shown $\sim 96 \%$ of $\mathrm{Al}_{2} \mathrm{TiO}_{5}$ phase with minor quantities of $\mathrm{Al}_{2} \mathrm{O}_{3}$ after sintering at $1550^{\circ} \mathrm{C}$. Further, the $\mathrm{TiO}_{2}$ peaks are completely absent in the pattern. It is well known that talc $\left(2 \mathrm{MgO} \cdot 2 \mathrm{Al}_{2} \mathrm{O}_{3} \cdot 5 \mathrm{SiO}_{2}\right)$ transform to clinoenstatite $\left(\mathrm{MgSiO}_{3}\right)$ close to $1100^{\circ} \mathrm{C}$ and at high temperatures, it decomposes to $\mathrm{MgO}$ and $\mathrm{SiO}_{2}$. In the case of $\mathrm{C}_{5}$ formulation, $\mathrm{Mg}^{2+}$ (MgO: $\left.1.5 \%\right)$ and $\mathrm{Si}^{4+}\left(\mathrm{SiO}_{2}: 3 \%\right)$ 
TABLE 3: Comparison of CTE values and hysteresis area.

\begin{tabular}{lcccc}
\hline Sample Id & \%TD & \%AT phase & CTE value $\left(30-1000^{\circ} \mathrm{C}\right)$ & Hysteresis area $\left(\mathrm{cm}^{2}\right)$ \\
\hline $\mathrm{C}_{0}$ & 85.13 & 92.04 & $1.09 \times 10^{-6} /{ }^{\circ} \mathrm{C}$ & 91 \\
$\mathrm{C}_{3}$ & 98.9 & 98 & $0.94 \times 10^{-6} /{ }^{\circ} \mathrm{C}$ & 68 \\
$\mathrm{C}_{5}$ & 98.63 & 95.5 & $0.4 \times 10^{-6} /{ }^{\circ} \mathrm{C}$ & 95 \\
\hline
\end{tabular}

TABLE 4: Comparison of flexural strength and hardness.

\begin{tabular}{lcccc}
\hline Sample & Flexural strength $(\mathrm{MPa})$ & \%increase in flexural strength & Hardness $\left(\mathrm{Kg} / \mathrm{mm}^{2}\right)$ & \%increase in hardness \\
\hline $\mathrm{C}_{0}$ & 8.53 & - & 150 & - \\
$\mathrm{C}_{3}$ & 8.61 & 0.94 & 180 & $20 \%$ \\
$\mathrm{C}_{5}$ & 25.89 & 203 & 200 & $33.33 \%$ \\
\hline
\end{tabular}

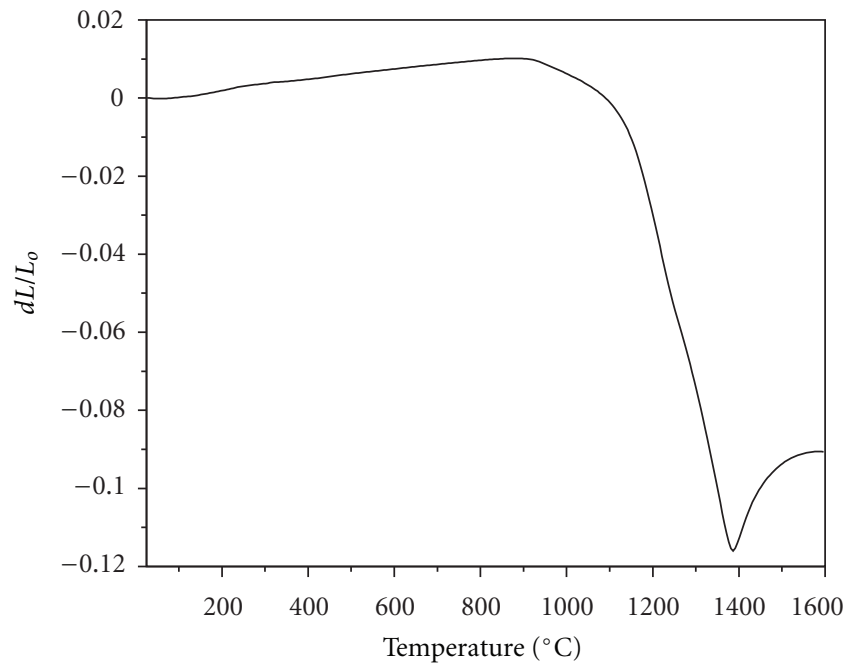

(a)

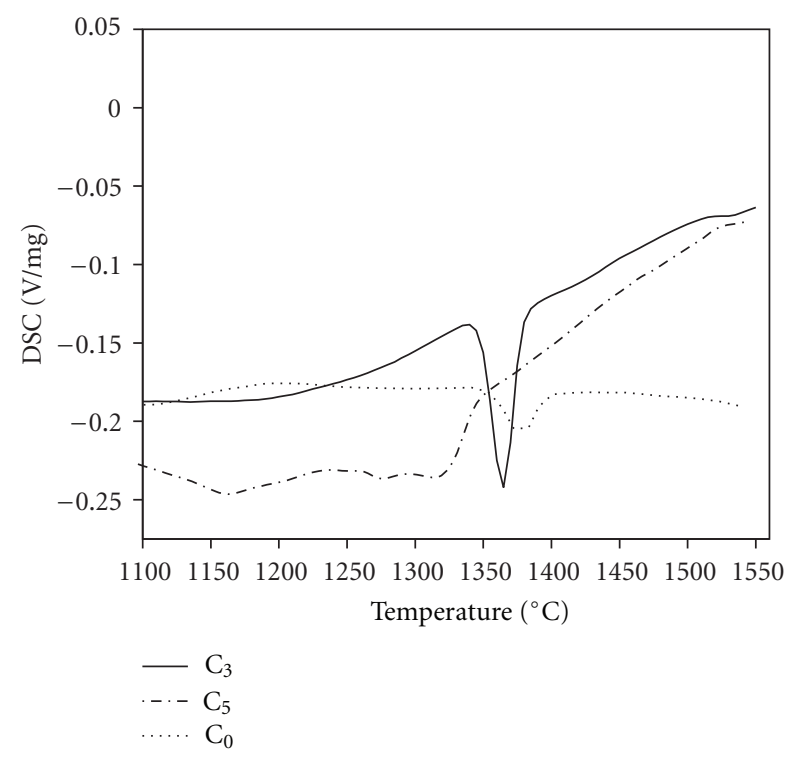

(b)

FIgURE 3: (a) Shrinkage curve of $\mathrm{C}_{0}$ and (b) DSC curves $\mathrm{C}_{0}, \mathrm{C}_{3}$, and $\mathrm{C}_{5}$.

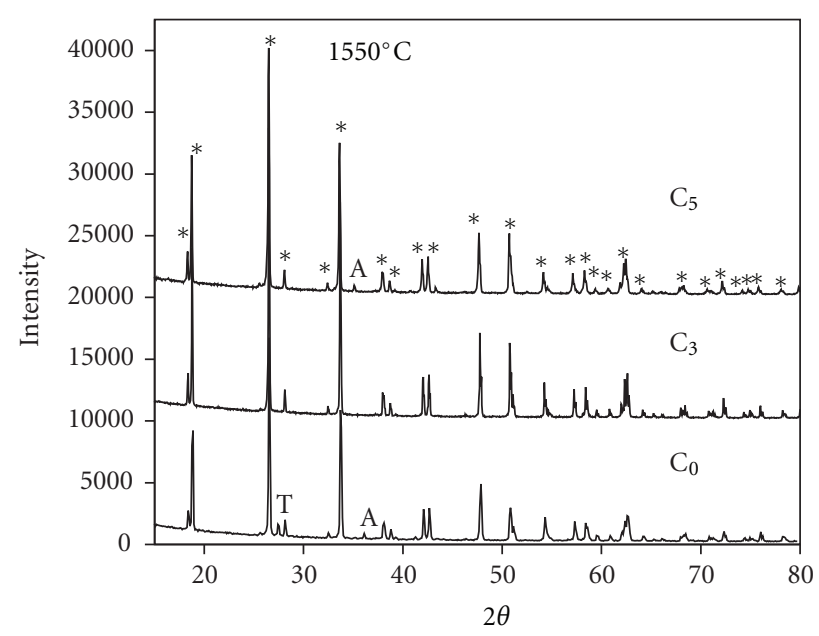

A: Alumina

T: Titania

*AT: Aluminum titanate

FIGURE 4: XRD patterns of sintered specimens $1550^{\circ} \mathrm{C}$.

ions undergo simultaneous lattice substitutions for $\mathrm{Al}^{3+}$ to stabilize $\mathrm{Al}_{2} \mathrm{TiO}_{5}$ stoichiometry. This leads to change in unit cell parameters due to addition of talc. The unit cell parameters and volume of sample $\mathrm{C}_{0}$ are $a=9.4315 \AA, b=$ $9.6385 \AA, c=3.590 \AA$, and $326.35(\AA)^{3}$. Whereas in sample $\mathrm{C}_{5}$ unit cell parameters and volume are $a=9.4651 \AA, b=$ $9.6715 \AA, c=3.5981 \AA$ and $329.37(\AA)^{3}$, which displaces the interplanar spaces. The dilation along crystallographic c-axis in talc added samples, further expected to improve phase stability of AT [17]. A larger distortion from the $\mathrm{C}_{0} \mathrm{com}-$ position can be attributed to the simultaneous substitution of $\mathrm{Si}^{4+}$ (ionic radius $=0.41 \AA$ ) and $\mathrm{Mg}^{2+}$ (ionic radius = $0.65 \AA$ ) replacing $\mathrm{Al}^{3+}$ in the lattice of $\mathrm{Al}_{2} \mathrm{TiO}_{5}$ matrix. $\mathrm{Al}_{2} \mathrm{TiO}_{5}$ formation process was led by nucleation and growth of grains and finally diffusion of reactant through the matrix and is controlled by the very slow reacting species. In addition to the multivalent state for titanium, that is, $\mathrm{Ti}^{3+} / \mathrm{Ti}^{4+}$ as a result of $\mathrm{Si}^{4+}$ substitution, the presence of $\mathrm{Mg}^{2+}$ ions 


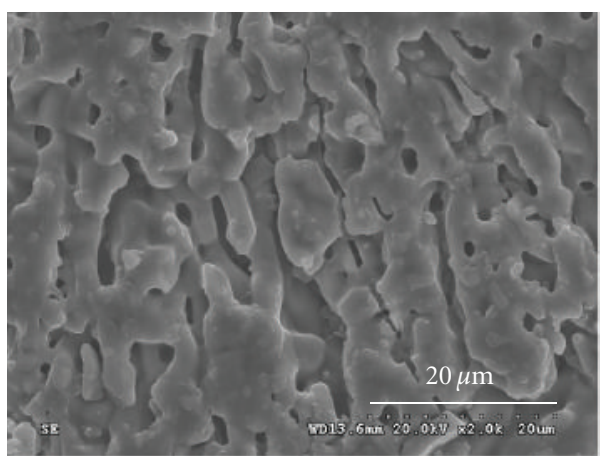

(a)

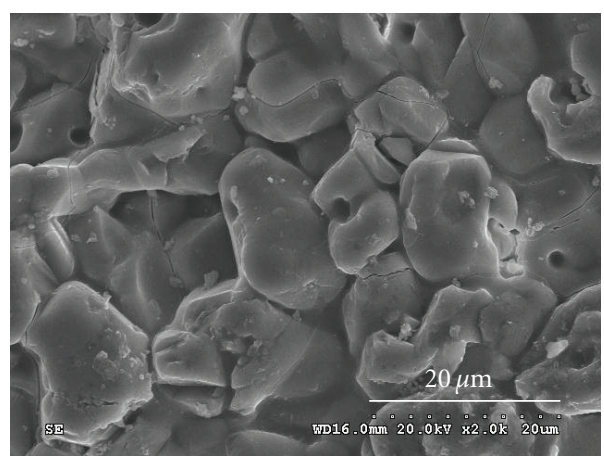

(b)

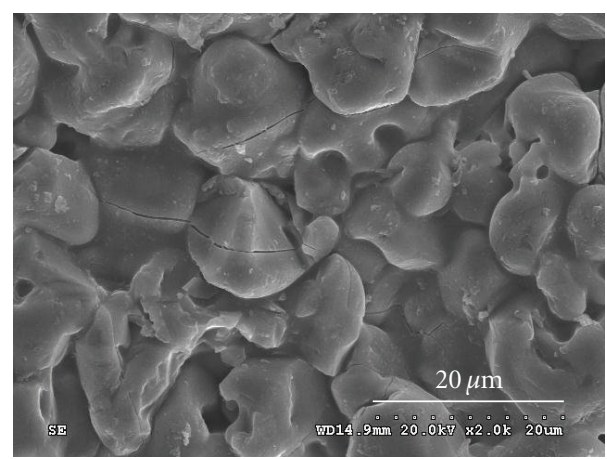

(c)

Figure 5: (a) SEM microstructure of $\mathrm{C}_{0}$, (b) SEM microstructure of $\mathrm{C}_{3}$, and (c) SEM microstructure of $\mathrm{C}_{5}$.

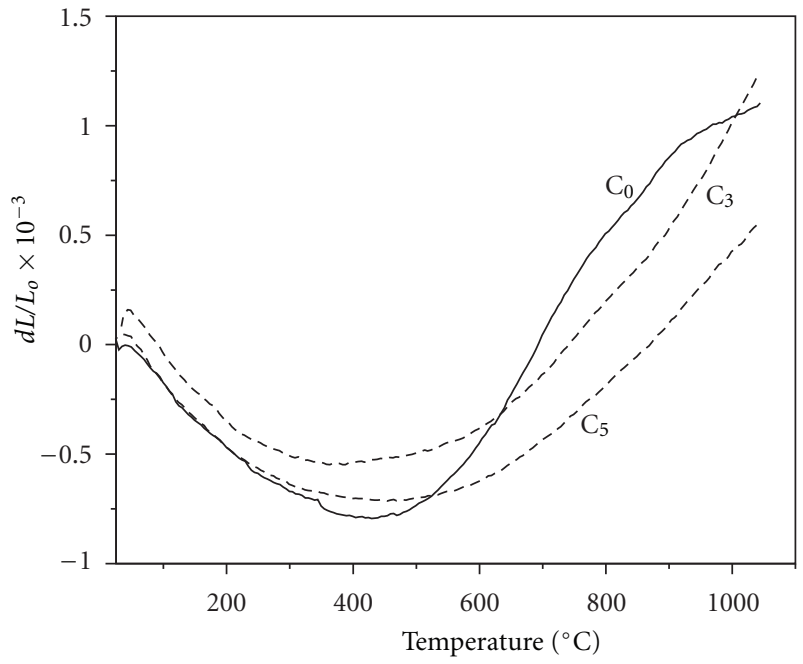

FIgURE 6: Thermal expansion curves of $\mathrm{C}_{0}, \mathrm{C}_{3}$, and $\mathrm{C}_{5}$.

that replaces $\mathrm{Al}^{3+}$ may result in oxygen vacancy formation $\left(\left(\mathrm{Al}^{3+}, \mathrm{Ti}^{3+}\right)_{2}\left(\mathrm{Ti}^{4+}\right)_{1}\left(\mathrm{O}_{5-\delta}^{2-}\right)\right.$. These vacancies promote the diffusion in the solid state enhancing densification.

Figures 5(a)-5(c) showed the microstructures of $\mathrm{C}_{0}$, $\mathrm{C}_{3}$, and $\mathrm{C}_{5}$ samples. From the microstructure of $\mathrm{C}_{3}$ and $\mathrm{C}_{5}$ samples, it is clear that they possess single AT phase, where as in the case of $\mathrm{C}_{0}$ some parent residual oxides still exist. Microstructural features do not show any significant

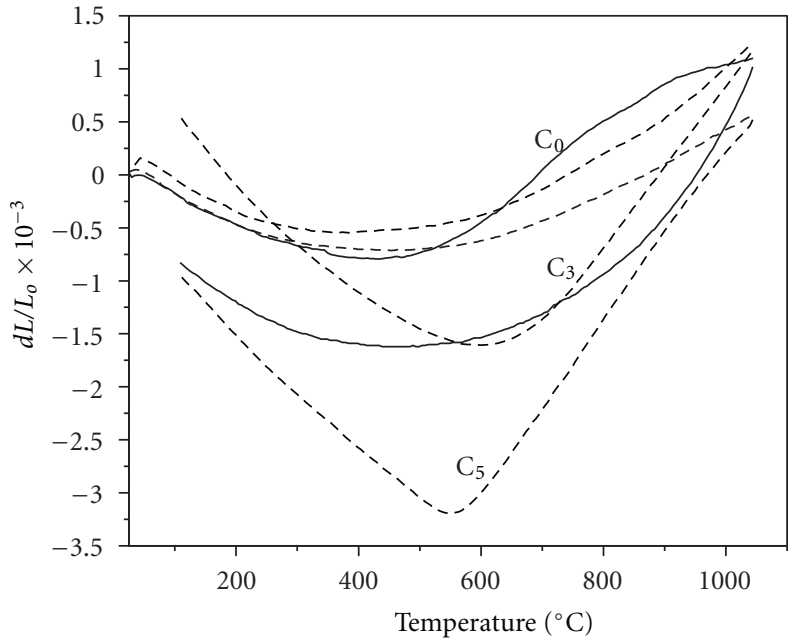

Figure 7: Thermal hysteresis of $\mathrm{C}_{0}, \mathrm{C}_{3}$, and $\mathrm{C}_{5}$.

variations in the grain size with both the additives $\left(\mathrm{C}_{3}, \mathrm{C}_{5}\right)$. However, considerable reduction in intergranular pores is observed with the addition of talc $\left(\mathrm{C}_{5}\right)$. The presence of additives enhanced the grain growth in AT ceramics.

3.2.2. Thermal Expansion and Thermal Hysteresis. Dilatometric expansion curve and thermal hysteresis were recorded while heating and cooling of the $\mathrm{C}_{0}, \mathrm{C}_{3}$, and $\mathrm{C}_{5}$ samples 


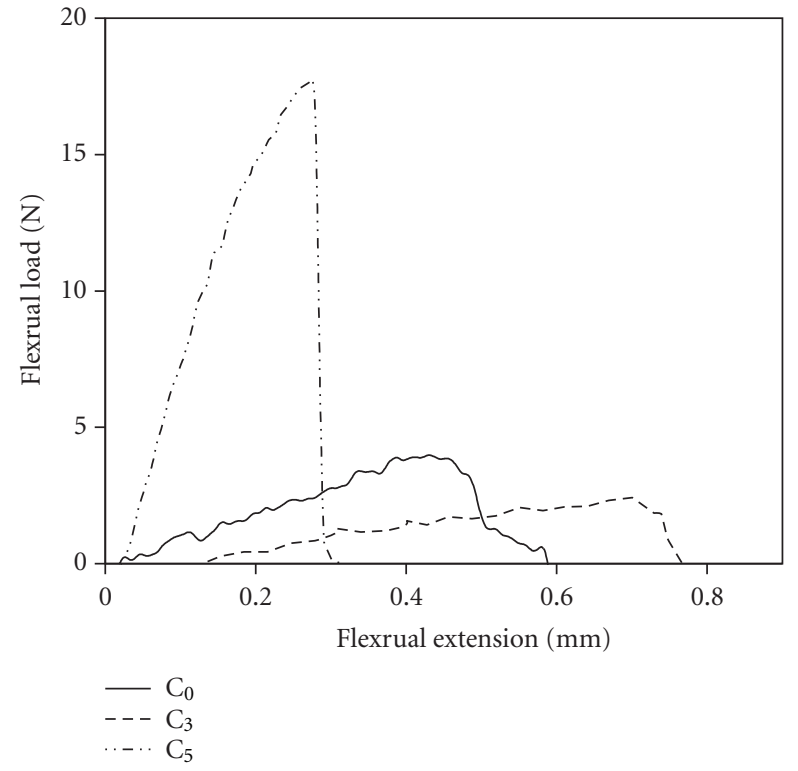

Figure 8: Load-displacement curves of $\mathrm{C}_{0}, \mathrm{C}_{3}$ and $\mathrm{C}_{5}$.

were shown in Figures 6 and 7, respectively. Table 3 lists the thermal expansion values of $\mathrm{C}_{0}, \mathrm{C}_{3}$, and $\mathrm{C}_{5}$ formulations from $30-1000^{\circ} \mathrm{C}$. It is evident that, the formulation $\mathrm{C}_{0}$ has a CTE value of $1.09 \times 10^{-6} /{ }^{\circ} \mathrm{C}$ followed by $\mathrm{C}_{3}$ with a marginally lower CTE value of $0.94 \times 10^{-6} /{ }^{\circ} \mathrm{C}\left(13 \%\right.$ less than $\left.\mathrm{C}_{0}\right)$ and the lowest value of $0.42 \times 10^{-6} /{ }^{\circ} \mathrm{C}\left(63 \%\right.$ less than $\left.\mathrm{C}_{0}\right)$ for $\mathrm{C}_{5}$ formulation. Thermal expansion curves of the entire samples initially contract till $450^{\circ} \mathrm{C}$. Thermal expansion curves of $\mathrm{C}_{0}$ exhibit a dissimilar behavior in comparison with $\mathrm{C}_{3}$ and $\mathrm{C}_{5}$ formulation. $\mathrm{C}_{0}$ sample exhibited a low expansion of $-1.97 \times 10^{-6} /{ }^{\circ} \mathrm{C}$ in comparison to $\mathrm{C}_{3}$ and $\mathrm{C}_{5}$ for which CTE values are $-1.71 \times 10^{-6} /{ }^{\circ} \mathrm{C}$ and $-1.74 \times$ $10^{-6} /{ }^{\circ} \mathrm{C}$, respectively. All samples have shown an expansion behavior beyond $450^{\circ} \mathrm{C}$ and $\mathrm{C}_{0}$ exhibited a significant slope change leading to the maximum expansion value. The temperature, beyond which the expansion becomes prominent, was regarded as the temperature at which healing of microcracks occurs that compensates the expansion effectively. Further, the curves corresponding to $\mathrm{C}_{0}$ are tapered into a plateau beyond $900^{\circ} \mathrm{C}$ unlike other samples with a positive slope.

Cooling curves also behaved differently with all the three samples. $\mathrm{C}_{0}$ formulation has shown a negative slope tapering into a plateau followed by the expansion. Initial contraction had $\alpha$ values of $6.08,7.75$, and $3.04 \times 10^{-6} /{ }^{\circ} \mathrm{C}$ (temperature regime, $1000-450^{\circ} \mathrm{C}$ ) and final expansion region had $\alpha$ values of $-4.37,-7.75$, and $-2.3 \times 10^{-6} /{ }^{\circ} \mathrm{C}$ (temperature regime, $450-100^{\circ} \mathrm{C}$ ) for $\mathrm{C}_{5}, \mathrm{C}_{3}$, and $\mathrm{C}_{0}$ respectively. Expansion below $450^{\circ} \mathrm{C}$ can be attributed to the reintroduction of micro-cracks healed while heating.

It is obvious that thermal properties of doped and undoped $\mathrm{Al}_{2} \mathrm{TiO}_{5}$ ceramics are mainly governed by the presence of microcracks and are affected by the crack closure or healing. Areas of the thermal hysteresis were recorded during heating up to $1000^{\circ} \mathrm{C}$ and cooling up to $100^{\circ} \mathrm{C}$ for formulations of $\mathrm{C}_{5}, \mathrm{C}_{3}$, and $\mathrm{C}_{0}$ were 95,68 and $91 \mathrm{~cm}^{2}$, respectively. Unlike other samples, $\mathrm{C}_{3}$ showed two closed loops where first loop is in the temperature regime of 1000 to $300^{\circ} \mathrm{C}$, which had $d L / L_{0}$ value less than $d L / L_{0}$ value of sample while heating, as expected. However, the second loop formed at $300^{\circ} \mathrm{C}$, exhibited a higher $d L / L_{0}$ value which is unusual. Probably this may be due to the transformation of microcracks into macro cracks due to high silica content (4.5\%) leading to a relatively low hysteresis area of $68 \mathrm{~cm}^{2}$ observed with $\mathrm{C}_{3}$ sample in comparison to $91 \mathrm{~cm}^{2}$ observed with $\mathrm{C}_{0}$ sample having close CTE values [17]. $\mathrm{C}_{5}$ sample exhibited hysteresis area of $95 \mathrm{~cm}^{2}$, which correlates well with the low CTE value $\left(0.42 \times 10^{-6} /{ }^{\circ} \mathrm{C}\right)$ as a result of compensation of expansion values. Microcrack density (number of microcracks/unit area estimated using several SEM images) of $\mathrm{C}_{5}$ sample was almost 3 times of that of the $\mathrm{C}_{0}$ sample confirming the above observations.

3.2.3. Flexural Strength and Hardness Measurements. Typical load-displacement curves obtained from the specimens $\mathrm{C}_{0}$, $\mathrm{C}_{3}$ and $\mathrm{C}_{5}$ which were subjected to 3 -point bend loading and is shown in Figure 8 . Though a minimum of $4-5$ specimens were tested in each case, for the sake of clarity, only one loaddisplacement curve for each condition are shown. Flexural strength $\left(\sigma_{f}\right)$ is calculated from the load displacement data as $\sigma_{f}=3 / 2 P L / b d^{2}$, where $P_{\max }$ is the maximum load, $L$ the span length, $b$ the width, and $d$ the thickness of the specimens. The flexural strength values are given in Table 4. $\mathrm{C}_{5}$ with talc doping exhibited the peak flexural strength before fracture (average, $28 \pm 3 \mathrm{MPa}$ ) which is $200 \%$ higher than the corresponding flexural strength values (average $8 \pm$ $4 \mathrm{MPa}$ ) of the $\mathrm{C}_{3}$ and $\mathrm{C}_{0}$ samples. It is evident from the data in Figure 8 that $\mathrm{C}_{0}$ and $\mathrm{C}_{3}$ materials show a similar unstable crack extension with load drop after attaining peak flexural stress. A close look at the load-displacement curves obtained from the flexural loading of the $\mathrm{C}_{3}$ and $\mathrm{C}_{0}$ samples (shown in Figure 8) has shown several load excursions while on attaining peak load depicting fracture over a wide range of strain followed by a gradual load drop. Poor strength in fracture behavior even with a high density (99\% of TD) can be attributed to increase in crack length and more number of macrocracks (crack length up to $30 \mu \mathrm{m}$, Figure 5(b)). It is obvious that poor density (85\%) and the high porosity are the factors that contribute in addition to the microcracks to the identical fracture behavior observed with $\mathrm{C}_{0}$ compositions.

Unlike the other samples, $\mathrm{C}_{5}$ composition exhibited initial rapid increase in the stress, reaching a peak value followed by the fracture. It is clear that, prior to the attainment of the peak flexural stresses, the material showed almost a linear increase in flexural stress with strain, indicating elastic deformation, before final failure. This can be attributed to the association of the existing large number of micro cracks (Figure 5(c), microcracks are restricted within the grain with maximum crack length $<10 \mu \mathrm{m}$ ) leading to the stable crack extension. Finally, the material fails with sudden load drop, which is an indication of rapid propagation of the macrocracks that resulted from coalescence of large number 


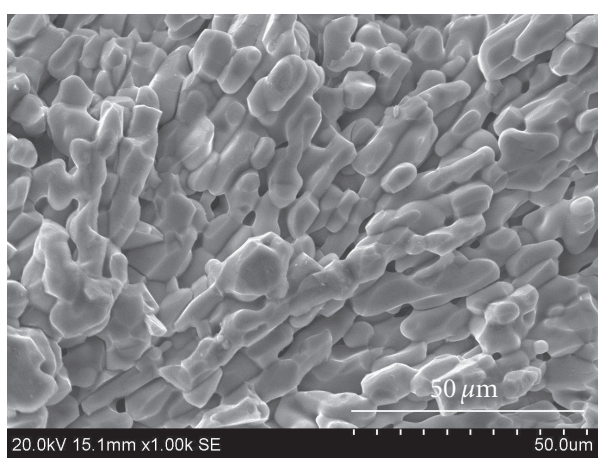

(a)

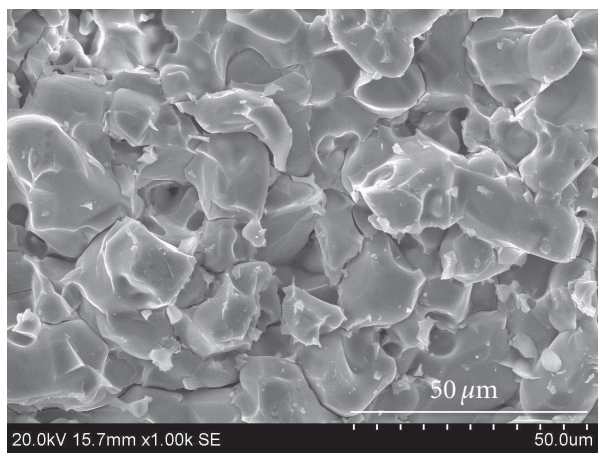

(c)

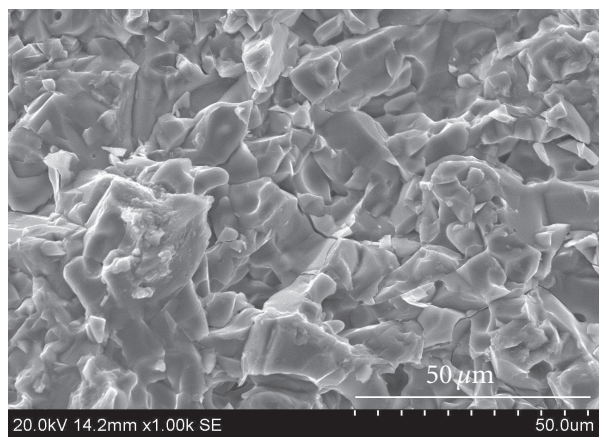

(e)

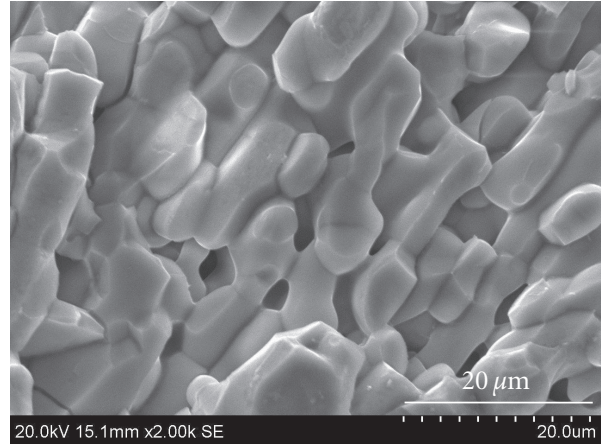

(b)

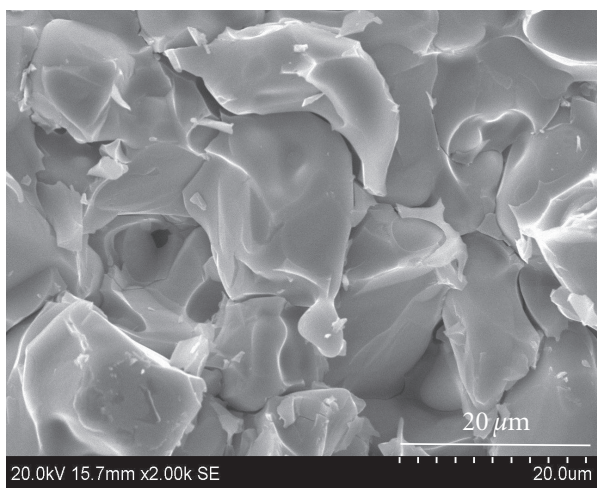

(d)

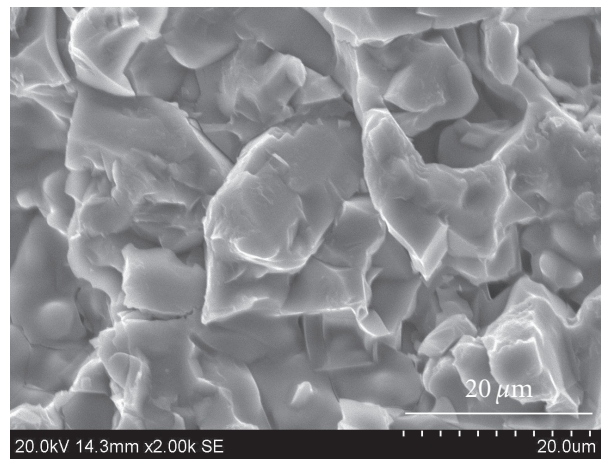

(f)

Figure 9: (a)-(b) Fractography microstructure of $\mathrm{C}_{0}$ at different magnifications, (c)-(d) fractography microstructure of $\mathrm{C}_{3}$ at different magnifications, and (e)-(f) fractography microstructure of $\mathrm{C}_{5}$ at different magnifications.

of micro cracks under local tensile loading. Hardness of the specimens $\mathrm{C}_{3}$ and $\mathrm{C}_{5}$ has shown an enhancement $20 \%$ and $33.3 \%$ with respect to $\mathrm{C}_{0}$. A relatively high hardness under identical densities could attribute to the marginal decrease in grain size observed with $\mathrm{C}_{5}$ samples.

SEM fractographs obtained from the specimens $\mathrm{C}_{0}, \mathrm{C}_{3}$, and $\mathrm{C}_{5}$ tested till the failure under flexural (3-point bend loading) testing are shown in Figures 9(a)-9(f). Though large number of fractographs at different magnifications is obtained in each of the specimen, for the sake of clarity, only one representative fractograph is depicted. These fractographs show an identical transgranular fracture. As discussed above, $\mathrm{C}_{5}$ composition is associated with more microcracks and the crack path while propagation needs to relocate for further crack extension as it encounters more and more microcracks. Such process needs higher fracture energy as compared to the $\mathrm{C}_{0}$ and $\mathrm{C}_{3}$ where microcrack densities were low.

\section{Conclusions}

Addition of kaolinite $\left(2 \mathrm{Al}_{2} \mathrm{O}_{3} \cdot 3 \mathrm{SiO}_{2} \cdot 2 \mathrm{H}_{2} \mathrm{O}\right)$ and talc $\left(\mathrm{Mg}_{3} \mathrm{Si}_{4} \mathrm{O}_{10}(\mathrm{OH})_{2}\right)$ in relatively low concentration of $8.8 \mathrm{wt} \%$ and $5 \mathrm{wt} \%$, respectively, resulted in enhanced densification leading to a substantial increase in percentage theoretical density to $99 \%$ in comparison with pure $\mathrm{Al}_{2} \mathrm{TiO}_{5}$ with $87 \%$ 
processed under identical conditions. Kaolinite and/or talc substitution results in multivalent titanium $\left(\mathrm{Ti}^{3+} / \mathrm{Ti}^{4+}\right)$ and oxygen vacancies in $\mathrm{Al}_{2} \mathrm{TiO}_{5}$ formulations promoting the enhanced diffusion and densification. Microstructural evaluations revealed transformation of porous lamellar type of structure of pure $\mathrm{Al}_{2} \mathrm{TiO}_{5}$ into relatively dense faceted grains with kaolinite and talc confirming higher density values. XRD studies have shown an improvement in $\mathrm{Al}_{2} \mathrm{TiO}_{5}$ phase content from $92 \%$ to a maximum of $98 \%$ with the addition of kaolinite. The enhancement in phase content was moderate in case of talc with a maximum of $95.5 \%$; however, DSC studies indicated a drop of $\sim 85^{\circ} \mathrm{C}$ in phase formation temperature. Substantial improvement in thermomechanical properties was observed with talc addition in comparison to kaolinite. A decrease in thermal expansion value of Talc-doped AT by $63 \%$ and an enhancement of flexural strength value by $200 \%$ is demonstrated in the present study. These properties found to have a good correlation with the presence and the mode of microcracks as revealed by microstructure and thermal hysteresis. Talc-doped $\mathrm{Al}_{2} \mathrm{TiO}_{5}$ formulation presently developed with superior thermomechanical properties can be explored for various potential applications.

\section{References}

[1] M. Nagano, S. Nagashima, H. Maeda, and A. Kato, "Sintering behavior of $\mathrm{Al}_{2} \mathrm{TiO}_{5}$ base ceramics and their thermal properties," Ceramics International, vol. 25, no. 8, pp. 681-687, 1999.

[2] G. Bruno, A. M. Efremov, B. R. Wheaton, and J. E. Webb, "Microcrack orientation in porous aluminum titanate," Acta Materialia, vol. 58, no. 20, pp. 6649-6655, 2010.

[3] R. Naghizadeh, H. R. Rezaie, and F. Golestani-fard, "The influence of composition, cooling rate and atmosphere on the synthesis and thermal stability of aluminum titanate," Materials Science and Engineering B, vol. 157, no. 1-3, pp. 20-25, 2009.

[4] K. Hamano, Y. Ohya, and Z. E. Nakagawa, "Crack propagation resistance of aluminium titanate ceramics," International Journal of High Technology Ceramics, vol. 1, no. 2, pp. 129-137, 1985.

[5] H. C. Kim, K. S. Lee, O. S. Kweon, C. G. Aneziris, and I. J. Kim, "Crack healing, reopening and thermal expansion behavior of $\mathrm{Al}_{2} \mathrm{TiO}_{5}$ ceramics at high temperature," Journal of the European Ceramic Society, vol. 27, no. 2-3, pp. 1431-1434, 2007.

[6] Y.X. Huang and A. M. R. Senos, "Effect of the powder precursor characteristics in the reaction sintering of aluminum titanate," Materials Research Bulletin, vol. 37, no. 1, pp. 99-111, 2002.

[7] G. Bruno, A. Efremov, B. Wheaton, I. Bobrikov, V. G. Simkin, and S. Misture, "Micro- and macroscopic thermal expansion of stabilized aluminum titanate," Journal of the European Ceramic Society, vol. 30, no. 12, pp. 2555-2562, 2010.

[8] C. H. Chen and H. Awaji, "Temperature dependence of mechanical properties of aluminum titanate ceramics," Journal of the European Ceramic Society, vol. 27, no. 1, pp. 13-18, 2007.

[9] B. Morosin and R. W. Lynch, "Structure studies on $\mathrm{Al}_{2} \mathrm{TiO}_{5}$ at room temperature and at $600^{\circ} \mathrm{C}$," Acta Crystallographica $B$, vol. 28, pp. 1040-1046, 1972.

[10] R. D. Skala, D. Li, and I. M. Low, "Diffraction, structure and phase stability studies on aluminium titanate," Journal of the European Ceramic Society, vol. 29, no. 1, pp. 67-75, 2009.
[11] A. Durán, H. Wohlfromm, and P. Pena, "Study of the behaviour of $\mathrm{Al}_{2} \mathrm{TiO}_{5}$ materials in reducing atmosphere by spectroscopic techniques," Journal of the European Ceramic Society, vol. 13, no. 1, pp. 73-80, 1994.

[12] I. M. Low, Z. Oo, and B. H. O'Connor, "Effect of atmospheres on the thermal stability of aluminium titanate," Physica B, vol. 385-386, pp. 502-504, 2006.

[13] V. Buscaglia, P. Nanni, G. Battilana, G. Aliprandi, and C. Carry, "Reaction sintering of aluminium titanate: i-effect of $\mathrm{MgO}$ addition," Journal of the European Ceramic Society, vol. 13, no. 5, pp. 411-417, 1994.

[14] A. Yoleva, S. Djambazo, D. Arseno, and V. Hristo, "Effect of $\mathrm{SiO}_{2}$ addition on thermal hysteresis of aluminum titanate," Journal of University of Chemical Technology and Metallurgy, vol. 45, no. 3, pp. 269-274, 2010.

[15] H. A. J. Thomas, R. Stevens, and E. Gilbart, "Effect of zirconia additions on the reaction sintering of aluminium titanate," Journal of Materials Science, vol. 26, no. 13, pp. 3613-3616, 1991.

[16] T. Korim, "Effect of $\mathrm{Mg}^{2+}$ - and $\mathrm{Fe}^{3+}$-ions on formation mechanism of aluminium titanate," Ceramics International, vol. 35, no. 4, pp. 1671-1675, 2009.

[17] J. Lan, C. Xiao-Yan, H. Guo-Ming, and M. Yu, "Effect of additives on properties of aluminium titanate ceramics," Transactions of Nonferrous Metals Society of China, vol. 21, no. 7, pp. 1574-1579, 2011.

[18] I. J. Kim, K. S. Lee, and G. Cao, "Low thermal expansion behavior of $\mathrm{ZrTiO}_{4}-\mathrm{Al}_{2} \mathrm{TiO}_{5}$ ceramics having high thermal durability between 750 and $1400^{\circ}$ c," Key Engineering Materials, vol. 22, pp. 2627-2632, 2002.

[19] L. Giordano, M. Viviani, C. Bottino, M. T. Buscaglia, V. Buscaglia, and P. Nanni, "Microstructure and thermal expansion of $\mathrm{Al}_{2} \mathrm{TiO}_{5}-\mathrm{MgTi}_{2} \mathrm{O}_{5}$ solid solutions obtained by reaction sintering," Journal of the European Ceramic Society, vol. 22, no. 11, pp. 1811-1822, 2002.

[20] T. Shimada, M. Mizuno, K. Katou et al., "Aluminum titanatetetragonal zirconia composite with low thermal expansion and high strength simultaneously," Solid State Ionics, vol. 101-103, no. 1, pp. 1127-1133, 1997.

[21] P. Oikonomou, C. Dedeloudis, C. J. Stournaras, and C. Ftikos, "Stabilized tialite-mullite composites with low thermal expansion and high strength for catalytic converters," Journal of the European Ceramic Society, vol. 27, no. 12, pp. 3475-3482, 2007.

[22] A. Tsetsekou, "A comparison study of tialite ceramics doped with various materials and tialite-mullite composites: microstructural, thermal and mechanical properties," Journal of the European Ceramic Society, vol. 25, no. 4, pp. 335-348, 2005.

[23] F. H. Perera, A. Pajares, and J. J. Meléndez, "Strength of aluminium titanate/mullite composites containing thermal stabilizers," Journal of the European Ceramic Society, vol. 31, no. 9, pp. 1695-1701, 2011.

[24] C. G. Shi and I. M. Low, "Use of spodumene for liquid-phasesintering of aluminium titanate," Materials Letters, vol. 36, no. 1-4, pp. 118-122, 1998.

[25] C. G. Shi and I. M. Low, "Effect of spodumene additions on the sintering and densification of aluminum titanate," Materials Research Bulletin, vol. 33, no. 6, pp. 817-824, 1998. 

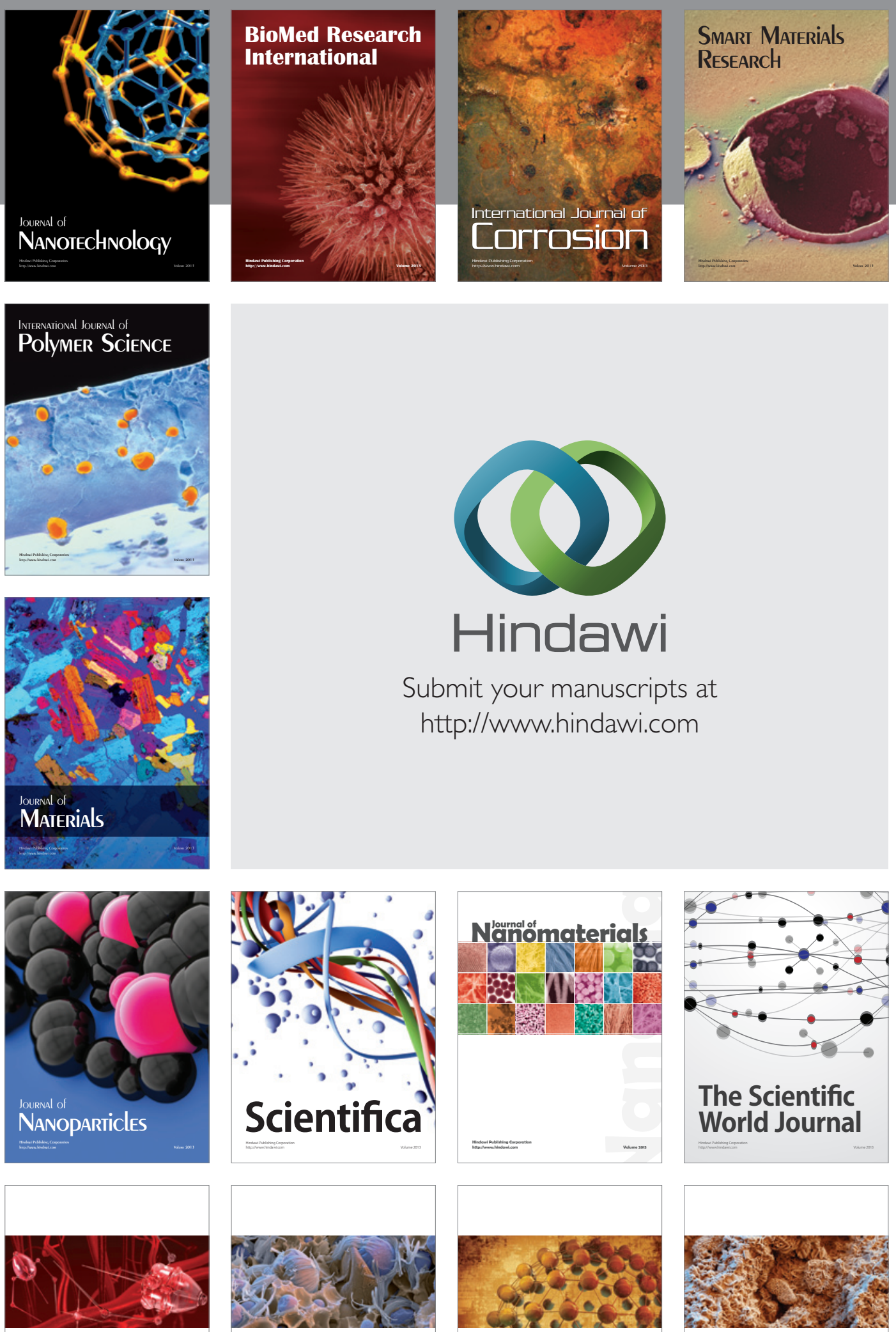

ISRN

Nanotechnology
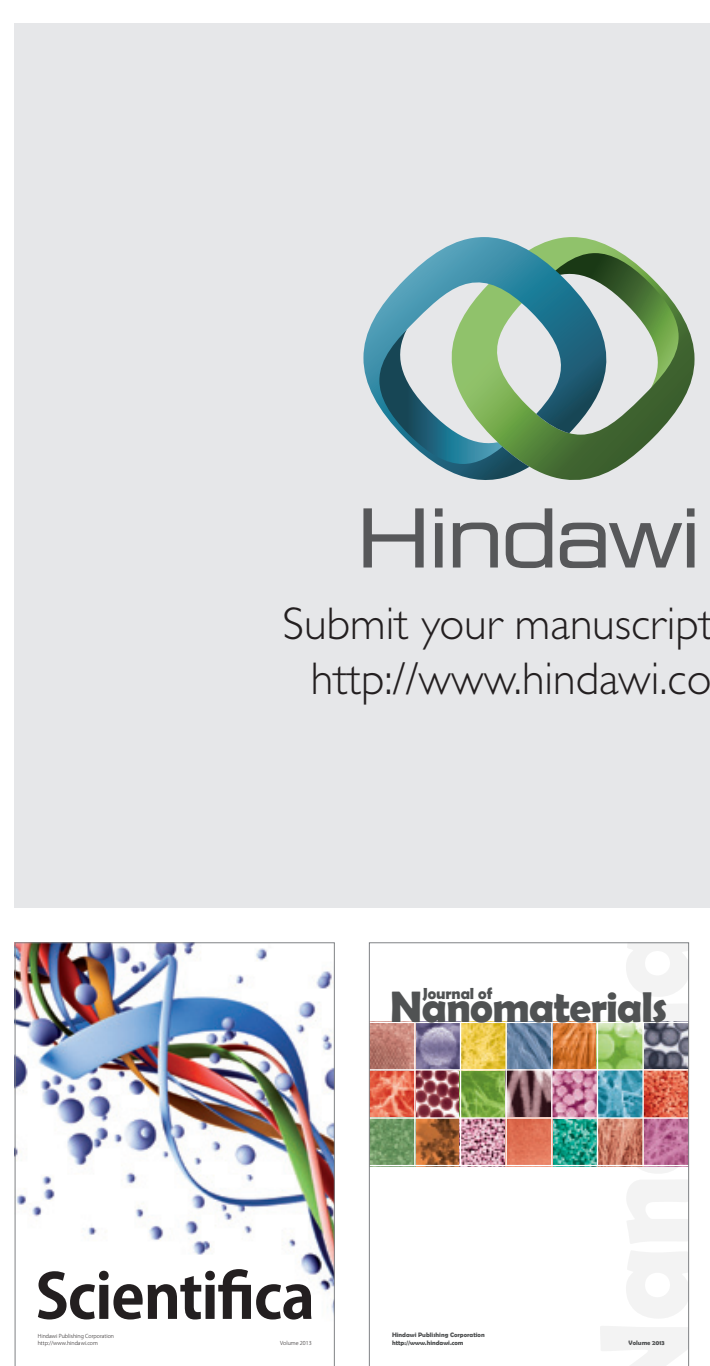

Submit your manuscripts at http://www.hindawi.com
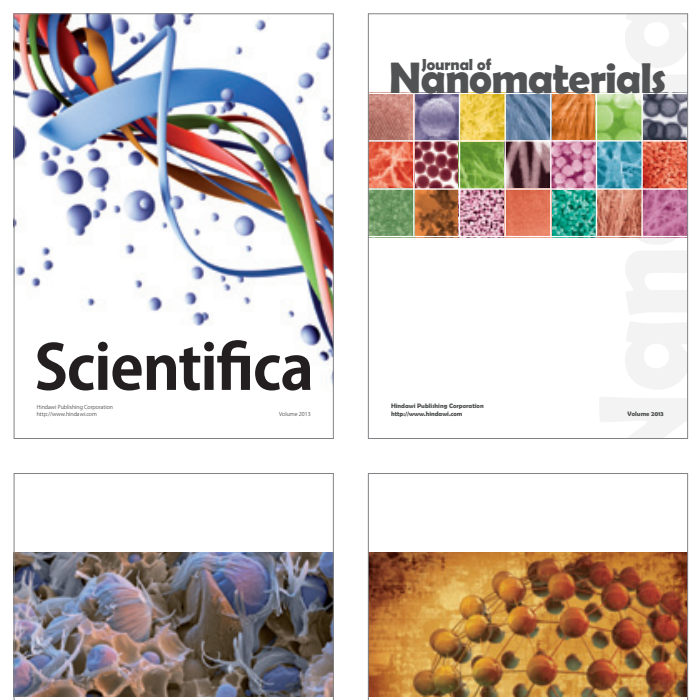

ISRN

Polymer Science

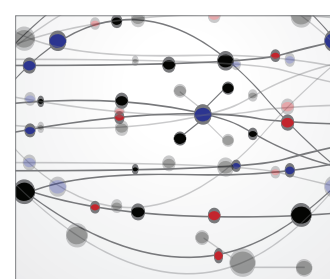

The Scientific World Journal

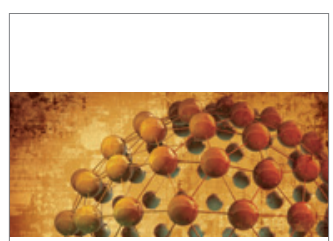

ISRN

Materials Science

\section{World Jounal}

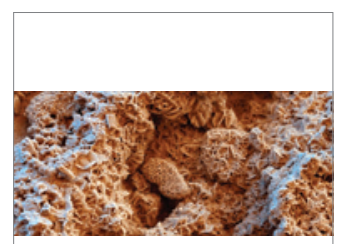

ISRN

Corrosion
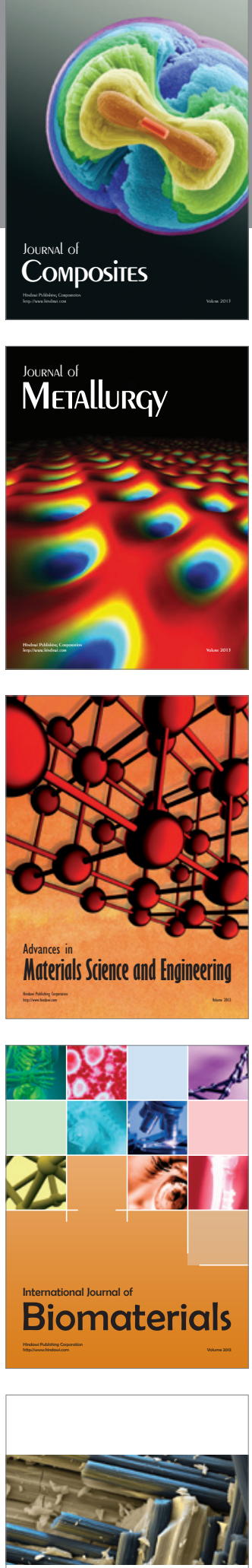

ISRN

Ceramics 